\title{
Spatial and Temporal Variation of Rainfall in IRAQ
}

\author{
Dr. Waleed I. AL-Rijabo; Hanee M.Salih \\ College of Education, Dept. of physics, Mosul University
}

\begin{abstract}
Rainfall in Iraq is characterized by unorganized distribution of both spatial and temporal. The annual, seasonal and monthly mean rainfall varies considerly with years. The recorded rainfall quantity in the different meteorological stations varies from location to another according to sea surface elevation and the geographical position of meteorological stations.

Variation of rainfall with space and time were studied in Iraq for the period (1980-2010) using 22 meteorological stations. Mean monthly, seasonally and annually values of rainfall were found in different meteorological stations. Winter months represent about (42-56) \% of total annual rainfall. The annual variability of rainfall in all these stations is high. Isohyetal method was used to estimate the mean monthly values of rainfall in Iraq. Simple and Multiple Regression Equations were found in Mosul, Baghdad and Basrah stations between rainfall and different meteorological elements.
\end{abstract}

\section{Introduction}

Rainfall analysis is important in different domains such as agricultural planning, water resources planning, runoff prediction, climatologically studies, environmental studies, stream flow estimation and human life activities. $(\mathbf{1}, 2,3)$ The amount, intensity and areal distribution of rainfall are essential factors in many hydrologic studies. ${ }^{(4,5)}$ Rainfall varies geographically, temporally and seasonally. ${ }^{(6,7)}$

Regional and seasonal variation of rainfall is very important for water resource planning. Temporal of rainfall intensity are extremely important in the rainfall- runoff process in urban area. ${ }^{(\mathbf{8})}$

Rainfall is also highly affected by meteorological elements and elevation from sea level, so simple and multiple correlations were found between these variables. ${ }^{(9,10)}$ Iraq is located between latitude $\left(29.5^{\circ}-37.22^{\circ} \mathrm{N}\right)$ and longitude $\left(38.45^{\circ}-48.45^{\circ} \mathrm{E}\right)$.

Fig (1) show the locations of (22) meteorological stations studied in Iraq.

The latitude, longitude and altitude for the different meteorological stations were presented in table (1). The objective of this research is to study the variation of rainfall with space and time in Iraq and to find simple and multiple correlations between the mean monthly values of rainfall and other meteorological elements.

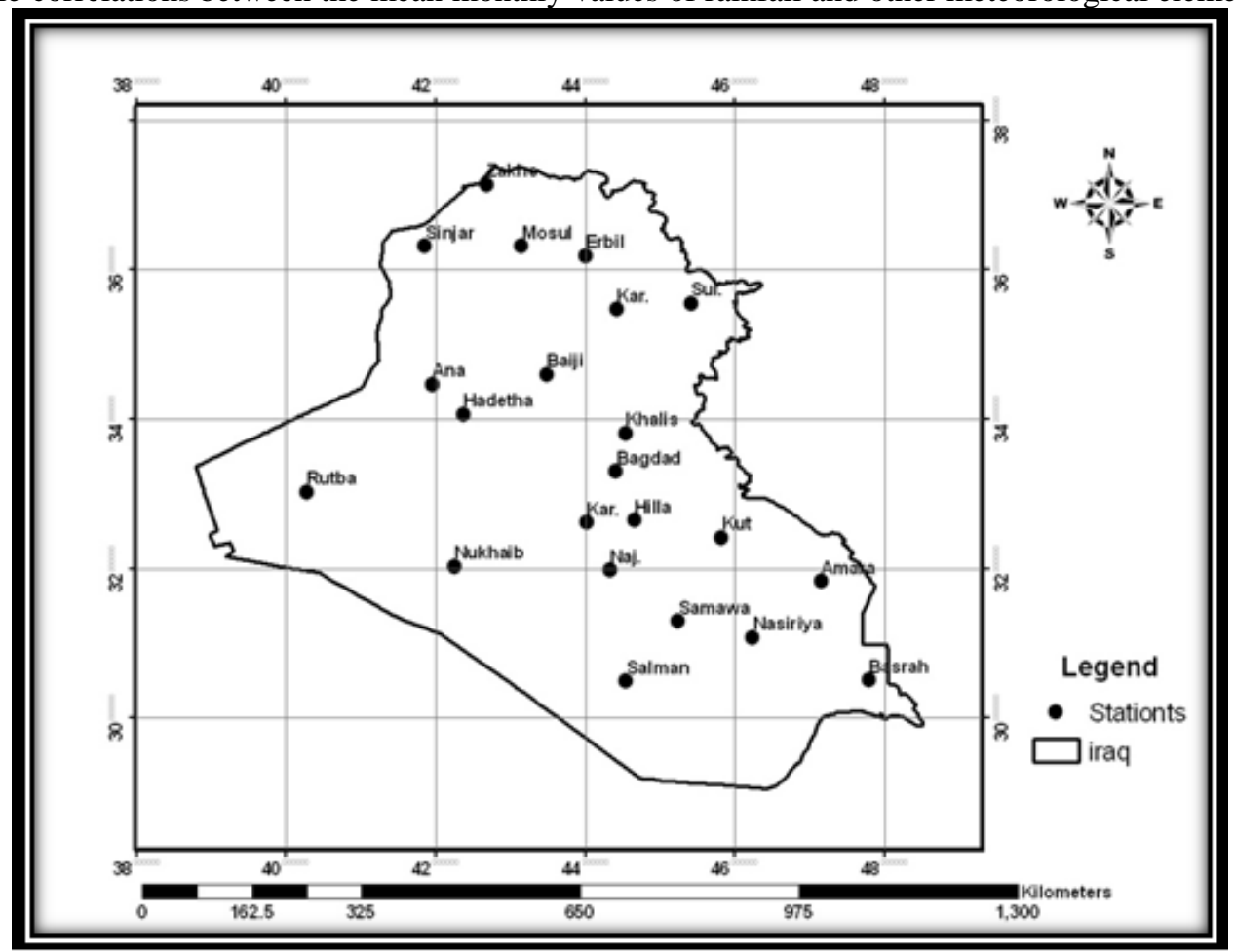

Fig (1): Map of Iraq and Location of Meteorological Stations 
Spatial and Temporal Variation of Rainfall in IRAQ

\begin{tabular}{|c|c|c|c|c|c|c|c|}
\hline Stations & Latitude & Longitude & Altitude(m) & Stations & Latitude & Longitude & Altitude(m) \\
\hline ZZakho & $33^{\circ} \mathbf{0 8}^{\prime}$ & $4 \mathbf{4 2}^{\circ} 41^{\prime}$ & 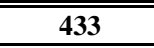 & "Hadetha & $33^{\circ} 04^{\prime}$ & 44222 & ב634 \\
\hline Mosul & $36^{\circ} 19^{\prime}$ & $43^{\circ} 09^{\prime}$ & 223 & Rutba & $33^{\circ} 02^{\prime}$ & $40^{\circ} 17^{\prime}$ & 630 \\
\hline Sinjar & $36^{\circ} 19^{\prime}$ & $40^{\circ} 51^{\prime}$ & 465 & Kut & $32^{\circ} 25^{\prime}$ & $45^{\circ} 49^{\prime}$ & 23 \\
\hline Erbil & 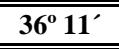 & $44^{\circ} 00^{\prime}$ & $4 \mathbf{4 2 0}$ & Nukhaib & $32^{\circ} \mathbf{0 2}^{\prime}$ & $42^{\circ} 15^{\prime}$ & 305 \\
\hline Sulaimaniya & $\mathbf{3 5}^{\circ}$ 33 $^{\prime}$ & $45^{\circ} 25^{\prime}$ & 883 & Karbala & $32^{\circ} 37^{\prime}$ & $44^{\circ} 01^{\prime}$ & 29 \\
\hline Kirkuk & $35^{\circ} 28^{\prime}$ & $44^{\circ} 25^{\prime}$ & 331 & Najaf & $31^{\circ} 59$ & $44^{\circ} 20^{\prime}$ & 33 \\
\hline Baiji & $34^{\circ} 36^{\prime}$ & $44^{\circ} 29^{\prime}$ & 1115 & Amara & $\begin{array}{l}31^{\circ} 50^{\prime} \\
\end{array}$ & $\overline{47^{\circ} 09^{\prime}}$ & $\overline{9}$ \\
\hline Ana & $34^{\circ} 28^{\prime}$ & 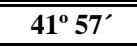 & 139 & Samawa & $31^{\circ} 18^{\prime}$ & $45^{\circ} 17^{\prime}$ & 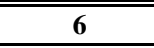 \\
\hline Khalis & $33^{\circ} 49^{\prime}$ & $44^{\circ} 32^{\prime}$ & 42 & Nasiriya & $31^{\circ} 05^{\prime}$ & 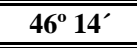 & 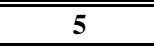 \\
\hline Bagdad & $33^{\circ} 1^{\prime}$ & $44^{\circ} 24^{\prime}$ & 32 & Salman & $\overline{30}^{\circ} \mathbf{3 0}^{\prime}$ & $44^{\circ} 32^{\prime}$ & 220 \\
\hline "Hilla & $32^{\circ} 3^{\prime}$ & 24439 & 27 & Basrah & $\begin{array}{l}0^{\circ} 31^{\prime} \\
\end{array}$ & 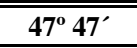 & $\overline{2}$ \\
\hline
\end{tabular}

Table (1): The Latitude, Longitude and Altitude of the different Meteorological Stations.

\section{Material Methods}

The rainfall year in Iraq is from 1 October to 31 May. Rainfall data for 22 Meteorological stations were collected for the period (1980-2010).

In our research we study:

1- Mean Monthly, seasonally and annually values of rainfall in all the 22 meteorological stations spread in Iraq.

2- Isohyetal method was used to estimate the mean monthly values of rainfall in Iraq using the GIS program.

3- Three locations, Mosul in the north of Iraq, Baghdad in the middle of Iraq and Basrah in the south of Iraq were used to find simple and multiple regressions equations between the mean monthly values of rainfall and other meteorological elements (Mean Air Temperature, Relative Humidity, Cloudiness, Atmospheric Pressure, and Evaporation).

\section{Result and discussions}

1- Study of mean monthly, seasonally and annually rainfall in all stations.

Table (2) shows the mean monthly rainfall in all stations during the rainy months. We can deduce from the table

a) The northern stations (Sulaimaniya, Zakho, Erbil, Kirkuk, Mosul, Sinjar) show high values of mean monthly rainfall in comparing with the middle and southern stations in Iraq. The topography, atmospheric depression and the nature of air masses blowing from the surrounding areas play an important role in the variation of monthly value of rainfall in these locations.

b) May and October gives the lowest values of rainfall in all stations in comparing with the other rainy months.

c) November and April gave value of rainfall greater than May and October but less than the other rainy months.

d) December, January, February and March gave the highest values of rainfall in comparing with the other rainy months in all stations.

e) Sulaimaniya station shows always the highest value of rainfall, while Nukhaib station shows the lowest value.

Table (3) shows the mean seasonal and annual values of rainfall in all stations.

Winter month receives about (42-56) \% of the annual rainfall and thus it represents the wettest season of the year. The vernal season receives a valuable amount rainfall and contributes (27-32) \% of the total annual rainfall. The autumn season contribute (15-27) \% of the total annual rainfall.

Summer season receive less than $0.5 \%$ of the total annual rainfall and for the most of the times can be neglected. The mean annual value of rainfall varies from location to another according to sea surface elevation of meteorological stations. The maximum mean annual value of rainfall was obtained in Sulaimaniya station (717) $\mathrm{mm}$ and lowest mean annual value was in Nukhaib station (87) $\mathrm{mm}$. 
Spatial and Temporal Variation of Rainfall in IRAQ

Table (2): mean monthly values of rainfall in all stations

\begin{tabular}{|c|c|c|c|c|c|c|c|c|c|c|c|c|}
\hline Station & $\stackrel{\mathrm{JA}}{\mathrm{N}}$ & $\underset{\text { BE }}{\mathrm{FE}}$ & $\underset{\mathbf{R}}{\mathbf{M A}}$ & $\begin{array}{r}A P \\
R\end{array}$ & $\underset{\mathbf{Y}}{\mathrm{MA}}$ & $\underset{\mathrm{N}}{\mathrm{JU}}$ & $\begin{array}{r}\mathrm{JU} \\
\mathrm{L}\end{array}$ & $\underset{\mathrm{G}}{\mathrm{AU}}$ & $\stackrel{\mathrm{SE}}{\mathrm{P}}$ & $\begin{array}{r}\mathrm{OC} \\
\mathrm{T}\end{array}$ & $\stackrel{\text { No }}{\mathbf{v}}$ & $\begin{array}{r}\mathrm{DE} \\
\mathrm{C}\end{array}$ \\
\hline Zaltho & 85.2 & 119 & 103 & 78.1 & 20.9 & 1.7 & 0.2 & 1.1 & 0.3 & 41.5 & 99.1 & 97.5 \\
\hline Mosul & 61.9 & 63.5 & 63.3 & 40.3 & 15.2 & 1.6 & 0.2 & 0.0 & 0.3 & 13.6 & 49.9 & 58.4 \\
\hline Sinjar & 63.9 & 62.9 & 63.6 & 28.1 & 18.5 & 1.3 & 0.1 & 0.0 & 0.5 & 16.4 & 39.4 & 62.8 \\
\hline Erbil & 74.5 & 74.4 & 75.2 & 54.7 & 119 & 1.3 & 0.5 & 0.1 & 0.7 & 30.8 & 52.1 & 80.3 \\
\hline Sul. & 122 & 110 & 107 & 87.2 & 39.7 & 19 & 0.0 & 0.0 & 1.4 & 33.2 & 96.5 & 118 \\
\hline Kirkulk & 68.7 & 66.8 & 50.0 & 43.5 & 13.8 & 0.2 & 0.3 & 0.1 & 1.0 & 14.7 & 45.6 & 569 \\
\hline Baiji & 36.2 & 35.8 & 30.5 & 20.0 & 11.5 & 0.5 & 0.0 & 0.0 & 1.0 & 89 & 269 & 29.8 \\
\hline Ana & 24.5 & 27.5 & 24.8 & 13.8 & 6.7 & 0.1 & 0.0 & 0.0 & 0.8 & 13.4 & 17.6 & 18.7 \\
\hline Khalis & 31.4 & 279 & 20.8 & 22.9 & 6.6 & 0.6 & 0.0 & 0.0 & 0.1 & 7.7 & 23.1 & 25.1 \\
\hline Bagdad & $\mathbf{5 6 . 0}$ & 449 & 33.5 & 27.3 & 11.5 & 0.2 & 0.3 & 0.0 & 0.7 & 10.3 & 30.0 & 41.8 \\
\hline Hilla & 20.4 & 149 & 13.7 & 13.0 & 2.3 & 0.0 & 0.0 & 0.0 & 0.2 & 3.8 & 14.6 & 16.3 \\
\hline Hadetha & 19.3 & 25.7 & 18.1 & 15.5 & 6.6 & 0.2 & 0.0 & 0.0 & 0.4 & 6.7 & 19.3 & 21.9 \\
\hline Rutba & 13.8 & 22.6 & 14.9 & 12.0 & 6.7 & 0.1 & 0.1 & 0.1 & 0.5 & 15.0 & 17.5 & 15.1 \\
\hline Kut & 33.5 & 15.8 & 23.5 & 15.7 & 4.5 & 0.0 & 0.0 & 0.0 & 0.1 & 3.7 & 20.5 & 22.3 \\
\hline Nulchaib & 10.1 & 11.7 & 10.9 & 14.5 & 2.6 & 0.1 & 0.0 & 0.0 & 0.1 & 6.8 & 14.7 & 15.5 \\
\hline Karbala & 179 & 15.0 & 14.6 & 12.4 & 2.8 & 0.0 & 0.0 & 0.0 & 0.3 & 4.3 & 11.2 & 15.0 \\
\hline Najaf & 15.9 & 14.5 & 11.9 & 14.0 & 4.5 & 0.0 & 0.0 & 0.0 & 0.0 & 4.6 & 14.5 & 15.5 \\
\hline Amara & 32.4 & 23.1 & 34.3 & 17.0 & 3.7 & 0.0 & 0.0 & 0.0 & 0.9 & 7.7 & 21.6 & 31.8 \\
\hline Samawa & 219 & 15.3 & 16.6 & 8.6 & 4.0 & 0.0 & 0.0 & 0.0 & 0.2 & 4.6 & 13.0 & 13.1 \\
\hline Nasiriya & 25.5 & 16.6 & 20.5 & 14.0 & 4.0 & 0.0 & 0.0 & 0.0 & 0.9 & 6.6 & 14.8 & 20.3 \\
\hline Salman & 21.1 & 16.5 & 18.2 & 13.5 & 4.5 & 0.2 & 0.0 & 0.0 & 0.0 & 2.5 & 21.3 & 20.8 \\
\hline Basrah & 32.8 & 22.2 & 22.3 & 14.2 & 2.6 & 0.0 & 0.0 & 0.3 & 0.0 & 6.8 & 16.7 & 25.8 \\
\hline
\end{tabular}

Table (3): Mean seasonal and annual values of rainfall in all stations

\begin{tabular}{|c|c|c|c|c|c|c|c|c|c|}
\hline \multirow{2}{*}{$\begin{array}{l}\text { Seasons } \\
\text { Station }\end{array}$} & \multicolumn{2}{|c|}{ Winter } & \multicolumn{2}{|c|}{ Spring } & \multicolumn{2}{|c|}{ Summar } & \multicolumn{2}{|c|}{ Autum } & \multirow{2}{*}{$\begin{array}{c}\text { Annual } \\
\text { Average }\end{array}$} \\
\hline & Mean & $\%$ & Mean & $\%$ & Mean & $\%$ & Mean & $\%$ & \\
\hline Zakho & 301.9 & 45.9 & 201.8 & 30.7 & 1.0 & 0.5 & 140.9 & 21.4 & 647.6 \\
\hline Mosul & 183.7 & 49.9 & 118.8 & 32.3 & 1.8 & 0.5 & 63.8 & 17.3 & 368.2 \\
\hline Sinjar & 189.6 & 53.0 & 110.3 & 30.8 & 1.4 & 0.4 & 56.3 & 15.7 & 357.5 \\
\hline Erbil & 229.1 & 50.2 & 141.7 & 31.1 & 1.9 & 0.4 & 83.5 & 18.3 & 456.3 \\
\hline Sul. & 350.2 & 48.8 & 233.8 & 32.6 & 1.9 & 0.3 & 131.1 & 18.3 & 717.0 \\
\hline Karkuk & 192.4 & 53.2 & 107.3 & 29.7 & 0.5 & 0.1 & 61.2 & 16.9 & 361.5 \\
\hline Baiji & 101.7 & 50.6 & 62.0 & 30.8 & 0.5 & 0.3 & 36.8 & 18.3 & 201.1 \\
\hline Ana & 70.7 & 47.9 & 45.3 & 30.6 & 0.1 & 0.0 & 31.8 & 21.5 & 147.8 \\
\hline Khalis & 84.4 & 50.8 & 50.4 & 30.3 & 0.6 & 0.4 & 30.9 & 18.6 & 166.3 \\
\hline Bagdad & 142.7 & 55.6 & 72.3 & 28.2 & 0.4 & 0.2 & 41.0 & 16.0 & 256.4 \\
\hline Hilla & 51.7 & 52.1 & 28.9 & 29.2 & 0.0 & 0.0 & 18.6 & 18.8 & 99.3 \\
\hline Hadetha & 66.9 & 50.0 & 40.2 & 30.1 & 0.2 & 0.1 & 26.4 & 19.8 & 133.6 \\
\hline Rutba & 51.5 & 43.5 & 33.6 & 28.4 & 0.2 & 0.2 & 33.0 & 27.9 & 118.3 \\
\hline Kut & 71.5 & 51.3 & 43.6 & 31.3 & 0.0 & 0.0 & 24.3 & 17.4 & 139.5 \\
\hline Nukhaib & 37.3 & 42.8 & 28.1 & 32.2 & 0.1 & 0.1 & 21.6 & 24.9 & 87.1 \\
\hline Karbala & 47.9 & 51.2 & 29.8 & 31.9 & 0.0 & 0.0 & 15.8 & 16.9 & 93.6 \\
\hline Najaf & 45.9 & 48.1 & 30.4 & 31.9 & 0.0 & 0.0 & 19.1 & 20.0 & 95.4 \\
\hline Amara & 87.4 & 50.6 & 55.0 & 31.8 & 0.1 & 0.0 & 30.2 & 17.5 & 172.6 \\
\hline Samawa & 50.4 & 51.7 & 29.2 & 29.9 & 0.0 & 0.0 & 17.9 & 18.3 & 97.4 \\
\hline Nasiriya & 62.5 & 50.7 & 38.5 & 31.2 & 0.0 & 0.0 & 22.2 & 18.0 & 123.2 \\
\hline Salman & 58.4 & 49.2 & 36.2 & 30.5 & 0.2 & 0.2 & 23.8 & 20.1 & 118.7 \\
\hline Basrah & 80.8 & 56.2 & 39.2 & 27.3 & 0.3 & 0.2 & 23.4 & 16.3 & 143.7 \\
\hline
\end{tabular}




\section{2- Study of Mean Areal Rainfall in IRAQ}

The main hydrometeorological problem related to the areal variation of rainfall is the estimation of rainfall over a given period of time. Isohyetal method was used to estimate the mean areal rainfall over Iraq.

Fig (2) and Fig (3) showed the distribution of mean monthly values of rainfall in ( $\mathrm{mm}$ ) during winter and spring months. Two main areas can be identified; the first one north of $\left(35^{\circ}\right)$ latitude and the second one are in the south of $\left(35^{\circ}\right)$ latitude.

Fig (4) showed the distribution of mean monthly values of rainfall during October and November. Three main areas can be identified; the first one in the further most of north and north east of Iraq, the second area extent to $\left(35^{\circ}\right)$, the third area is in the south of $\left(35^{\circ}\right)$.

The mean areal rainfall over Iraq during the rainy months are $(10.5,24.7,33.8,32.6,32,30.3,22.3$, and 7.8) $\mathrm{mm}$ in October, November, December, January, February, March, April and may respectively.
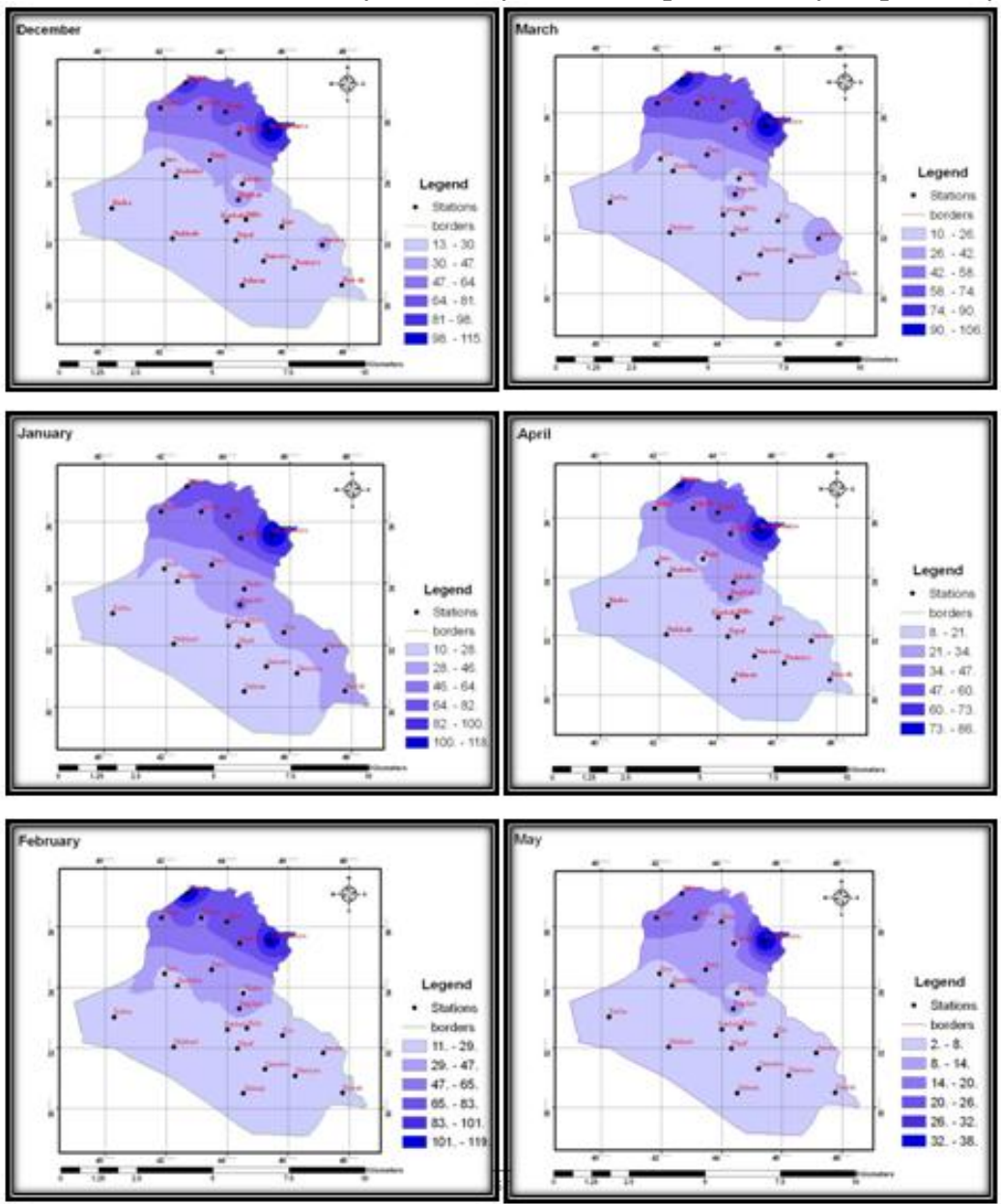

Fig (2): Isohyetal Map of Iraq during Winter season

Fig (3): Isohyetal Map of Iraq

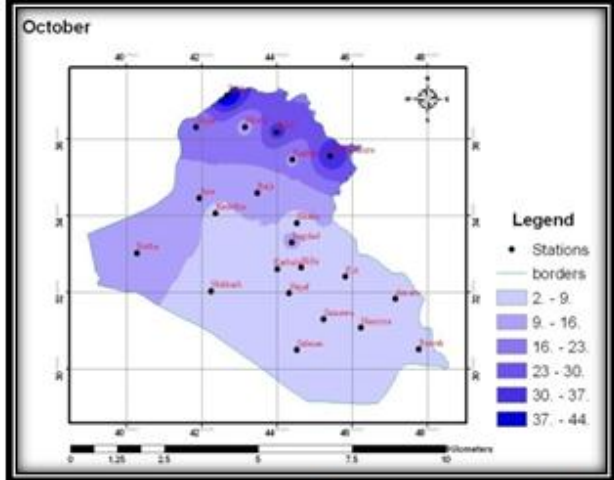
during Spring season

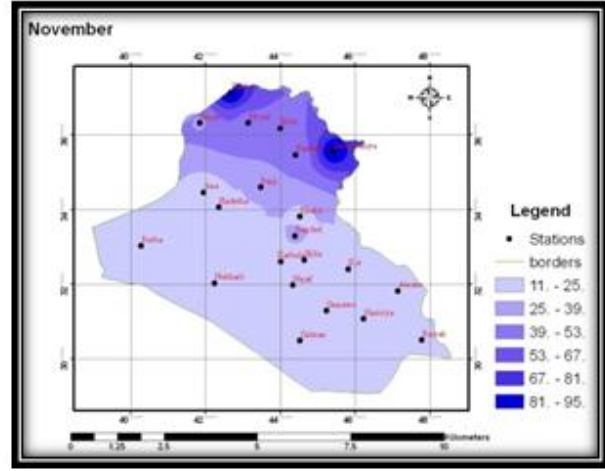

Fig (4): Isohyetal Map of Iraq during Autumn season 


\section{3- Correlations between rainfall and different meteorological elements in three locations in IRAQ}

Mosul, Baghad and Basrah were chosen to study the correlations between mean monthly values of rainfall and mean monthly values of different meteorological elements, Fig (5) show these correlations. A highly positive correlations were obtained between mean monthly values of rainfall and mean monthly values of (Relative Humidity, Cloudiness, atmospheric pressure) in these stations. The values of correlation coefficients (R) between (Rainfall \& RH) are $(0.94,0.90,0.94)$, and between (Rainfall \& Cloudiness) are $(0.87,0.83,0.80)$ and between (Rainfall \& atm. Pressure) are $(0.76,0.86,0.88)$ in Mosul, Baghdad and Basrah respectively. A highly negative correlation was obtained between mean monthly values of rainfall and mean monthly values of (Air Temperature, Evaporation). The values of correlation coefficient of (R) between (Rainfall \& Temp.) are (-0.95, 0.94, -0.95), and between (Rainfall \& Evap.) are (-0.87, -0.84, -0.88) in Mosul, Baghdad and Basrah respectively. Multiple correlations were obtained between the mean monthly values of rainfall and the mean monthly values of the meteorological elements (Temperature, Relative Humidity, Atmospheric pressure, Cloudiness, Evaporation). Table (4) shows these multiple correlations and their correlation coefficients. These correlations are very important for hydrological and climatologically studies.
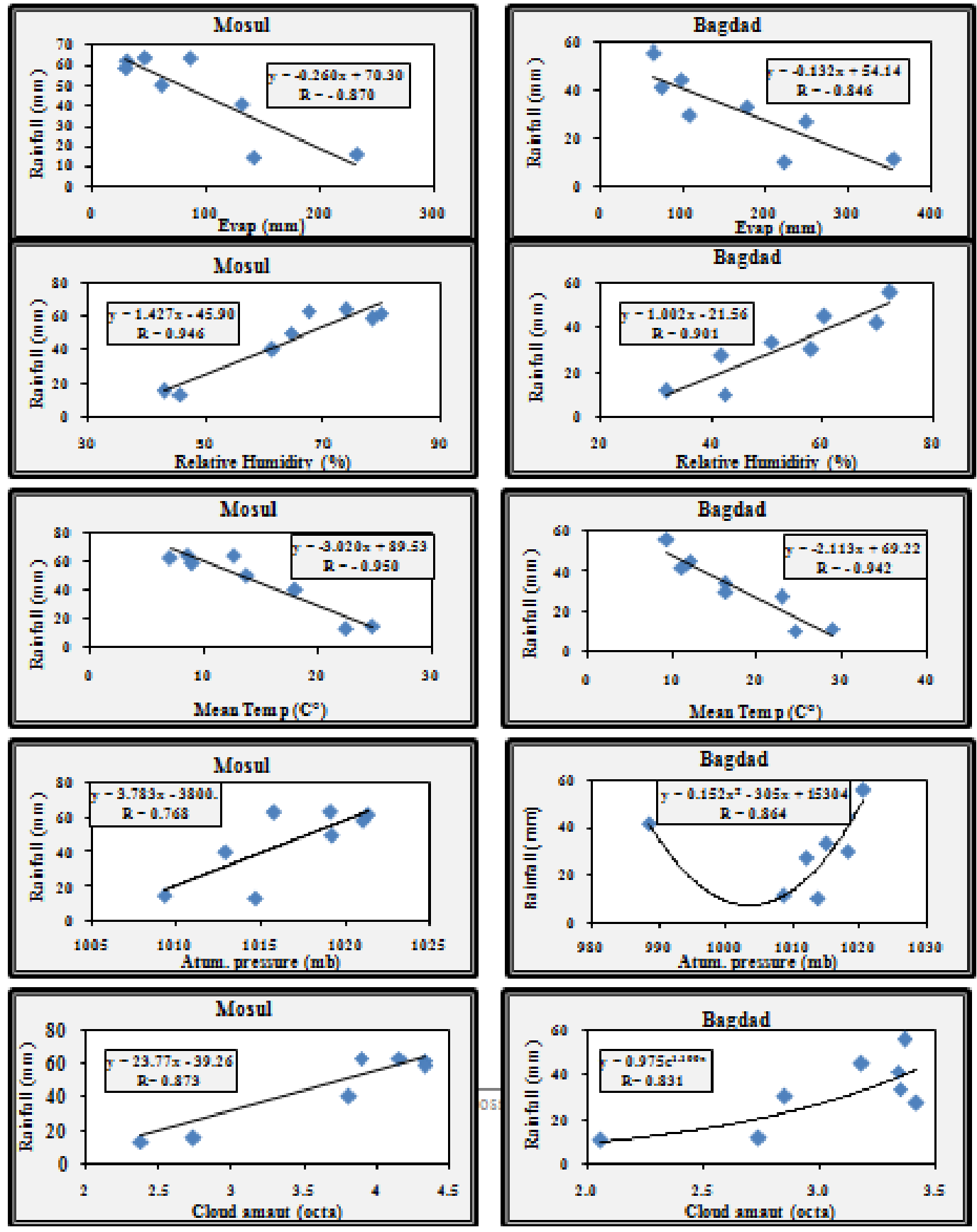


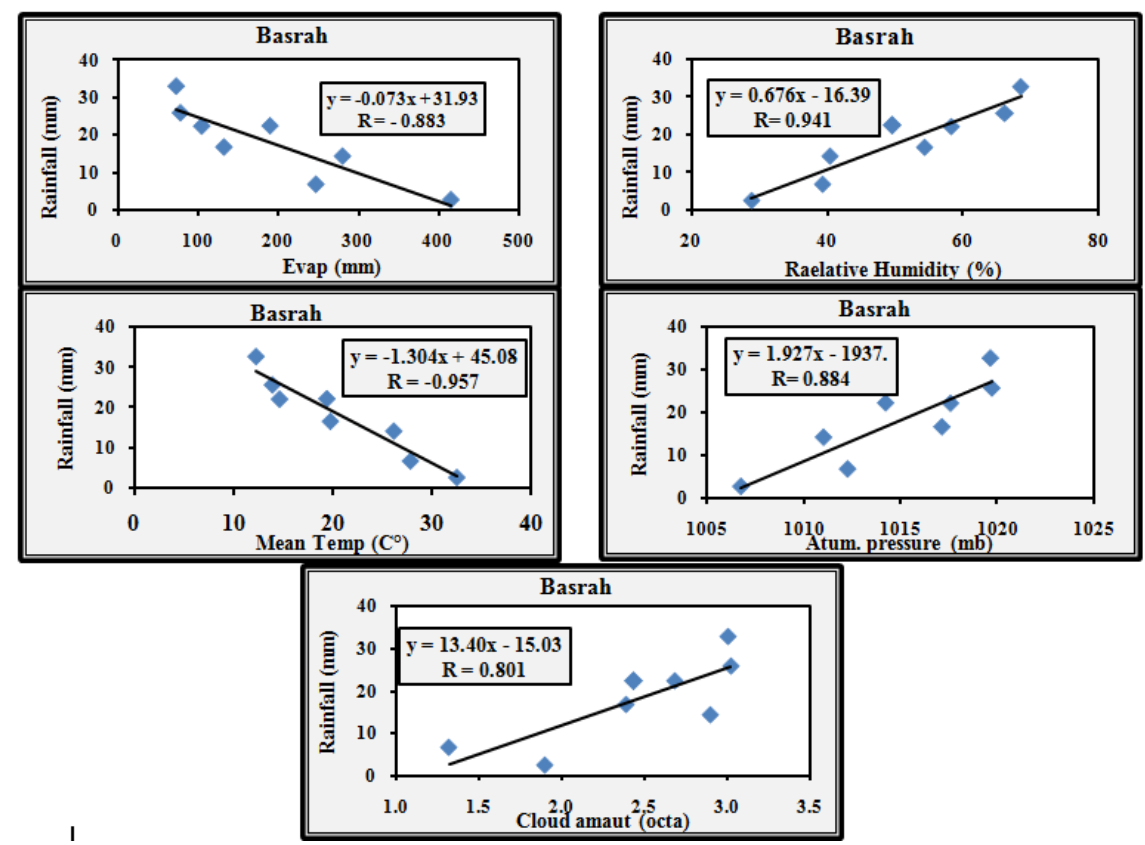

Fig (5): Correlations of the mean monthly values of Rainfall and different Meteorological Elements in Mosul, Baghdad, and Basrah stations

Table (4): Multiple correlations between Rainfall and all the other meteorological elements in Mosul, Bagdad and Basrah stations.

\begin{tabular}{|c|c|c|}
\hline Stations & Equations & $\mathbf{R}$ \\
\hline Mosul & $\begin{array}{c}\text { Rainfall }=-0.242 * \text { Evap }+1.413 * \text { RH }-4.487 * \text { Tmean }-8.061 * \text { Pressur }-20.9 * \text { Cloud } \\
+8312.6\end{array}$ & 0.996 \\
\hline Bagdad & $\begin{array}{c}\text { Rainfall }=0.106 * \text { Evap }+0.867 * \text { RH }-1.528 * \text { Tmean }+0.296 * \text { Pressure } \\
+9.033 * \text { Cloud }-332.357\end{array}$ & 0.993 \\
\hline Basrah & $\begin{array}{c}\text { Rainfall }=-2.20 * \text { Evap }+1.894 * \mathrm{RH}+0.554 * \text { Tmean }-8.717 * \text { Pressure }+ \\
1.70 * \text { Cloud }+8794.1\end{array}$ & 0.999 \\
\hline
\end{tabular}

\section{Conclusion}

1- Mean monthly values of rainfall all over Iraq that is calculated by contour lines method are $(33.8,32.6$, 32, 30.2, 22.6, 7.8, 10.5, 24.7) mm during December, January, February, March, April, May, October, November months respectively.

2- The distribution maps of mean monthly values of rainfall in Iraq during winter and spring months showed two main areas, first one northern of $35^{\circ}$ latitude, second one is in south of it. During Oct and Nov three areas had been characterized, the first one is in further most of north and north east of Iraq, the second one extend to $\left(35^{\circ}\right)$ latitude and the third one in south of $\left(35^{\circ}\right)$ latitude.

3- Simple regression equations were found between mean monthly values of rainfall and mean monthly values of different meteorological elements (Mean Air Temperature, Relative Humidity, Cloudiness, Atmospheric Pressure, and Evaporation) in station of Mosul, Baghdad and Basrah station. These correlations gave high correlation coefficient between these variables.

4- Multiple regression equations were found between mean monthly values of rainfall and mean monthly values of different meteorological elements which gave high correlation coefficient $(0.996,0.993$, and 0.999) in Mosul, Baghdad, Basrah respectively.

\section{References}

[1]. Subramaya , k. , (1984), "Engineering Hydrology", Tata McGraw-Hill Publishing Company Limited.

[2]. Hatzzian, A.N., Katsoulis, B., Pnevmatikos, J., and Antakis, V. , (2007) , "Spatial and Temporal Variation of Precipitation in Greece and Surrounding Regions Based on Global Precipitation Climatology Project Data", Journal of climate, vol.21 pp. 13491370.

[3]. Smt Sarjini Achary and Gangadhara Bhat , H. , (2013), "Sptial and Temporal Variation of Rainfall in the Selected stretches of Southern Karnataka Coast”, Proceedings of Global Engineering, Scince and Technology Conference, Singapore, ISBN: 978-1922069-32-0.

[4]. Mutreja , K. N. , (1990) "Applied Hydrology", Tata McGraw-Hill Publishing Company Limited.

[5]. Juny , H.S. , Gyu , H.L. and Jai , H.O. , (2001), "Interpretation of the transient variation of precipitation amount in Seoul" , American Meteo. Society, vol.14, No.13. 
[6]. Thiam, El. and Singh, V. P. , (2002), "Space-time freguency analysis of rainfall, Runoff and temperature in Csamance River Basin , Southern Senegal , West Africa", University of Louisiana, vol. 28 , No .3 , pp(259-292).

[7]. Ovuka, Mira and Seven , (2002), "Rainfall variability in Murany and District, Kenya : Meteorological data farmer precipitation", Gotebory University, Gotebory-Sweden. 82 A(1), pp(107-119).

[8]. $\quad$ Bruce, J.P. and Clark, R.H., (1986), "Introduction to Hydrometeorology" . Pergamon press Ltd.

[9]. Waleed I. Al_Rijabo and Diyar A. Bleej , (2010), "Variation of Rainfall with space and Time in Duhok Governorate" , J. Edu. \& Sci. , vol.23, No.1.

[10]. Limia M.F.Mustafa , (2012), "Spatial and Temporal Variation of Rainfall in Ninava Governorate”, J.Edu. \& Sci. , vol.25 ,No.4. 